\title{
THE
}

4-17-2013

\section{Organochlorine Pollutants in Western Antarctic Peninsula Sediments and Benthic Deposit Feeders}

\author{
Lin Zhang \\ Rebecca Dickhut \\ Dave DeMaster \\ Kari Pohl \\ Rainer Lohmann \\ University of Rhode Island, rlohmann@uri.edu
}

Follow this and additional works at: https://digitalcommons.uri.edu/gsofacpubs

The University of Rhode Island Faculty have made this article openly available.

Please let us know how Open Access to this research benefits you.

This is a pre-publication author manuscript of the final, published article.

Terms of Use

This article is made available under the terms and conditions applicable towards Open Access

Policy Articles, as set forth in our Terms of Use.

\section{Citation/Publisher Attribution}

Zhang, L., Dickhut, R., DeMaster, D., Pohl, K., \& Lohmann, R. (2013). Organochlorine pollutants in western Antarctic peninsula sediments and benthic deposit feeders. Environmental Science \& Technology, 47(11), p. 5643-5651.

Available at: http://dx.doi.org/10.1021/es303553h

This Article is brought to you for free and open access by the Graduate School of Oceanography at DigitalCommons@URI. It has been accepted for inclusion in Graduate School of Oceanography Faculty Publications by an authorized administrator of DigitalCommons@URI. For more information, please contact digitalcommons-group@uri.edu. 


\section{Organochlorine Pollutants in Western Antarctic Peninsula Sediments and Benthic Deposit Feeders.}

\footnotetext{
Lin Zhang ${ }^{1,2}$, Rebecca Dickhut ${ }^{3 \dagger}$, Dave DeMaster ${ }^{4}$, Kari Pohl ${ }^{1}$, and Rainer Lohmann $^{1^{*}}$

${ }^{1}$ Graduate School of Oceanography, University of Rhode Island, Narragansett, Rhode Island 02882-1197, USA

${ }^{2}$ now at Marine Chemistry \& Geochemistry,Woods Hole Oceanographic Institution, Clark Lab, MS\#25, Woods Hole, MA, 02543

${ }^{3}$ Virginia Institute of Marine Science, The College of William \& Mary, Gloucester Point, Virginia

${ }^{\dagger}$ deceased

${ }^{4}$ Department of Marine, Earth, and Atmospheric Sciences, North Carolina State University, Raleigh, NC, 27695-8208, USA

* corresponding author: Tel: 001-401-874-6612, Fax: 001-401-874-6811,E-mail: lohmann@gso.uri.edu
} 


\section{Abstract}

Sediments and benthic deposit feeding holothurians were collected near the Palmer Long Term Ecological Research grid during the austral winter of 2008. Polychlorinated biphenyls (PCBs) and organochlorine pesticides (OCPs) were measured in Western Antarctic Peninsula continental shelf sediments, porewater, and benthic biota. Concentrations and fluxes in sediments decreased sharply away from the tip of the peninsula towards its interior. Sedimentary PCB fluxes were order of magnitues lower than reported elsewhere, supporting the notion of a pristiner Antarctic environment. Hexa-chlorinated biphenyls dominated (40$100 \%$ ) the PCB profiles in the sediments, while tri-chlorinated biphenyl 28 was the most abundant PCB congener in the porewater. PCB and OCP concentrations in holothurians were comparable to concentrations in other low trophic level biota in the Antarctic food web (i.e., krill). The partitioning of PCBs and OCPs between the sediments and porewater can be explained by a dualmode model which included both organic carbon and black carbon as partitioning media. Alternatively, a simpler one-parameter prediction assuming coal tar-like organic carbon performed equally well in explaining porewater concentrations The majorities of PCBs (63-94\%) in the Western Antarctic Peninsula sediments were bound to black carbon or recalcitrant tar-like organic carbon, thereby lowering porewater concentrations. PCBs and OCPs in the holothurians were in equilibrium with those in the porewater. 


\section{Introduction}

The Southern Ocean plays a pivotal role in the global carbon cycle and climate change ${ }^{(1)}$, leading to an increasing amount of scientific activities and the establishment of numerous research stations in the Antarctic ${ }^{(2)}$. Increased anthropogenic activity will very likely place extra stress on Antarctic ecosystems, which includes the contamination by anthropogenic organic pollutants ${ }^{(3)}$. Several baseline studies around deserted and current scientific research stations have been conducted to investigate local levels of contaminants ${ }^{(2,4,5)}$. They have found patchy distribution of persistent organic pollutants (POPs) and higher concentrations of polychlorinated biphenyls (PCBs) and polycyclic aromatic hydrocarbons (PAHs) adjacent to scientific station ${ }^{(5,6)}$, indicating contamination from human activities. Atmospheric and oceanic long range transport may also contribute to the presence of POPs in the Antarctic ${ }^{(7)}$. Fuoco et al. showed that PCBs were supplied by surrounding seas to the Ross Sea region ${ }^{(8)}$. However, the 'westerlies' and Antarctic Circumpolar Current act as physical/dynamical barriers that may significantly impede the atmospheric and oceanic transport of POPs from the north ${ }^{(3,9)}$. The inter-hemispheric exchange in the atmosphere is slow as reflected by the strong hemispheric gradients in gas phase concentrations of POPs ${ }^{(10)}$ and the north-south atmospheric delivery is less efficient than west-east within the Southern Hemisphere ${ }^{(3)}$. It would take several hundred years for seawater formed in the Arctic to travel to the Southern Ocean according to the ${ }^{14} \mathrm{C}$ data ${ }^{(11,12)}$ and modeling studies found the transport time for 
North Atlantic Deep Water from $47^{\circ} \mathrm{N}$ to $30^{\circ} \mathrm{S}$ is about 150 years (25 300 years) and another 95 years ( $25 \sim 422$ years) from $30^{\circ} \mathrm{S}$ to the Southern Ocean ${ }^{(13,14)}$ Since the first detection of PCBs and organochlorine pesticides (OCPs) in the Antarctic five decades ago ${ }^{(15,16)}$, there have been dozens of investigations on the occurrence, distribution of POPs in Antarctic air ${ }^{(17-20)}$, water ${ }^{(8,21)}$, soil ${ }^{(2,4)}$, sediments ${ }^{(22,23)}$, and biota ${ }^{(24-33)}$. Most of the studies were conducted at the tip of the Western Antarctic Peninsula (WAP) and Ross Sea area ${ }^{(2,6)}$. The physicochemical properties of POPs plus the seasonal change in the sea ice result in POPs entering the Antarctic coastal waters. POPs deposit on the sea ice and migrate into it. Following sea ice melting, the POPs are released back into the water, where they can enter the sea ice microbial community, and surface phytoplankton and then be transferred within the food web. POPs in the pelagic food web in the Antarctic were found to biomagnify with trophic level ${ }^{(30,33)}$. Due to their lipophilic nature, POPs can be carried by sinking particulate organic matter (POC) downward to the sediments. When the POC is remineralized by microbes, POPs are released back to the water column or porewater, rendering them available for uptake by the benthos and microbes. To the best of our knowledge, no studies have been conducted on the fate of POPs in sediments and benthic biota in Antarctica. Previous studies suggested benthic-pelagic coupling during winter could occur ${ }^{(34)}$ when the pelagic food sources are limited. Partitioning of POPs from benthic media to benthos may represent another bioaccumulation pathway along the WAP food web. 
POPs in the benthic media may be less available for uptake by biota due to the presence of black carbon. Previous studies have shown that adsorption onto black carbon present in the sediments can greatly reduce the availability of POPs in the porewater ${ }^{(35-39)}$. Yet these studies have focused on areas strongly affected by human activities and have not investigated pristine locations such as Antarctic. Passive samplers have been proven to be a robust sampling device to determine truly dissolved porewater concentration of POPs ${ }^{(35-40)}$. The importance of black carbon for reducing bioavailability in the porewater thus can be assessed using passive sampler ${ }^{(35-40)}$.

The objectives of this study are to 1) provide the first data of POPs in the WAP benthic biota and porewater; 2) investigate the bioaccumulation of POPs by benthic deposit feeders and determine whether different feeding strategies affect body burdens; and 3) study the influence of sediment geochemistry (e.g., black carbon) on the porewater concentrations of POPs in the WAP sediments.

\section{Materials and Methods}

\section{Sampling Locations}

Sediments and benthic biota samples were collected from five different locations on the WAP shelf near the Palmer long term ecological research (LTER) grid in

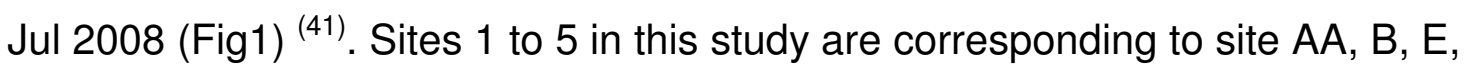
$\mathrm{F}$, and $\mathrm{G}$ in the FOODBANCS-2 project $^{(42)}($ http://www.soest.hawaii.edu/expeditions/blog_antarctica/foodbancs2.html). The sampling locations covered a relatively large spatial range with site 1 close to 
Livingstone Island $\left(62.60^{\circ} \mathrm{S}, 60.50^{\mathrm{W}} \mathrm{W}\right)$ which is in the Southern Ocean away from the northern end of WAP, site 2 near Palmer Station $\left(64.67^{\circ} \mathrm{S}, 64.05^{\mathrm{W}} \mathrm{W}\right)$, and the rest further south towards the interior of the WAP (see Table 1 for details). The most northern site 1 is about $565 \mathrm{Km}$ away from the most southern site 5 . The top sediments $(0-5 \mathrm{~cm})$ were collected at approximately $600 \mathrm{~m}$ depth using a Bowers and Connelly Megacorer (OSIL, Havant, Hampshire, UK, www.osil.co.uk). The benthic megafaunal samples were collected using a $5.5 \mathrm{~m}$ semi-balloon otter trawl (2cm mesh). The sediments and biota samples were stored in clean amber glass jars with aluminum foil lined lids at $-20^{\circ} \mathrm{C}$ until analysis.

\section{Tumbling experiment}

A non-depletive, polyethylene (PE) passive sampling technique was employed to measure the freely dissolved concentrations of PCBs and OCPs. Passive sampling has been shown by previous studies to be a reliable and robust approach to obtain porewater concentrations of POPs ${ }^{(35-40)}$. The detailed methods have been described elsewhere ${ }^{(37)}$. Approximately $100 \mathrm{~g}$ wet weight (40 - $60 \mathrm{~g}$, dry weight) of sediments was added to clean, $250 \mathrm{~mL}$ flat-bottom glass jars. A PE sampler $(\sim 2 \mathrm{~g})$ and sodium azide (final concentration $=0.43$ $\mu \mathrm{mol} / \mathrm{mL}$ ) were also added to each jar which was then filled with Milli-Q water. Laboratory blanks were composed of a PE sheet, sodium azide, and Milli-Q water. The sodium azide acted as a biocide to avoid any biological interference with diffusion into the passive sampler. The sealed sediment-water slurries were placed on a shaker table and agitated until equilibrium was reached ( $>$ weeks). 
During this time, the samples were kept in an environmental chamber at $20 \pm$ $1^{\circ} \mathrm{C}$. Performance reference compounds (PRCs) were pre-impregnated in the PE and used to quantify the equilibrium between porewater-PE system following literature methods ${ }^{(43,44,44)}$. See detailed information on PRCs in SI on page 6 and physical-chemical properties used in Table SI-7.

\section{Laboratory Analysis}

Details on organic carbon (OC), black carbon (BC), sample extraction, analysis, derived sedimentary fluxes, and QA/QC are given in the SI.

\section{Partitioning models}

The partitioning of hydrophobic POPs between the lipids in biota and porewater is governed by the partitioning coefficient ( $\left.\mathrm{K}_{\text {lipid }}\right)$ when equilibrium is reached.

$$
K_{\text {lipid }}=\frac{C_{\text {lipid }}}{C_{\text {porewater }}}
$$

Where $\mathrm{C}_{\text {lipid }}$ is the concentrations of POPs in the lipids of biota ( $\mathrm{ng} / \mathrm{g}$ lipid) and $\mathrm{C}_{\text {porewater }}$ is the concentrations of POPs in the porewater (pg/L). Traditionally, absorption into $\mathrm{OC}$ was considered as the dominant sorption process between sediments and porewater. This process can be modeled as:

$$
\begin{aligned}
& K_{D}=f_{T O C} K_{O C} \\
& K_{O C}=\frac{C_{\text {sediments }}}{C_{\text {porewater }}}
\end{aligned}
$$

where $K_{D}$ is the observed partitioning coefficients between the sediment and the pore water $(\mathrm{mL} / \mathrm{g}), \mathrm{C}_{\text {sediments }}$ is the concentration of PCBs and OCPs in the sediments (ng/g dry weight), $f_{\text {TOC }}$ is the OC fraction present in the sediment (\%,g 
$\mathrm{OC} / \mathrm{g}$ sediment dry weight) and $\mathrm{K}_{\mathrm{OC}}$ is the equilibrium partitioning coefficient between $\mathrm{OC}$ and water $(\mathrm{mL} / \mathrm{g})$.

Absorption of POPs from water into octanol has been used as a standard partitioning reference to describe the absorptive partitioning to general organic phases. A slope close to 1 of the linear regression between $\log \mathrm{K}_{\mathrm{OC}}$ and $\log \mathrm{K}_{\mathrm{OW}}$ indicated similar processes controlled partitioning into OC and n-octanol ${ }^{(45)}$.

$$
\log \mathrm{K}_{\mathrm{OC}}=0.97^{\star} \log \mathrm{K}_{\mathrm{OW}}-0.12
$$

The $\mathrm{K}_{\mathrm{OC}}$ values were derived from the linear free energy relationship (LFER) with corresponding octanol-water partitioning coefficients $\left(K_{\circ}\right)$ (Equation $\left.\square\right)^{(45)}$. The $\mathrm{K}_{\mathrm{OC}}$ LFER relationship was derived for only biogenic source $\mathrm{OC}$ and humic substances that were not produced by burning (pyrogenic source $>50^{\circ} \mathrm{C}$ ) and not altered by diagenetic effects ${ }^{(46)}$. In other words, the derived $\mathrm{K}_{\mathrm{OC}}$ did not include any BC contribution which is suitable for this partitioning model (Equation $\square)$. The OC is also defined as amorphous organic carbon (AOC) in other studies (36)

The following bimodal partitioning model has been proposed to account for the partitioning into $\mathrm{BC}^{(47)}$ :

$$
K_{D}=f_{O C} K_{O C}+f_{B C} K_{B C} C_{\text {porewater }}^{n-1}
$$

where $f_{B C}$ is the fraction of $\mathrm{BC}$ present in the sediment $(\mathrm{g} \mathrm{BC} / \mathrm{g}$ sediment, dry weight), $C_{\text {porewater }}$ in this equation $\square$ has a unit of $\mathrm{ng} / \mathrm{mL}, K_{B C}$ is the equilibrium partitioning coefficients of POPs between BC and porewater $(\mathrm{mL} / \mathrm{g})$, which is dominated by adsorptive partitioning. And $n$ is the Freundlich exponent for 
adsorption onto $\mathrm{BC}$, which reflects non-linear partitioning and often is found to be between 0.3 and $1^{(48)}$. See detailed information on $\mathrm{K}_{\mathrm{BC}}$ and $\mathrm{K}_{\mathrm{OW}}$ in Table SI-7. Previous studies also provided an alternative one-carbon model approach (total organic carbon) to interpret the partitioning of pollutants between sediments and porewater $^{(36,49-52)}$. The TOC include both AOC and BC. Hawthorne et al ${ }^{(36)}$ compiled log $\mathrm{K}_{\mathrm{TOC}}\left(\mathrm{L} / \mathrm{kg}_{\mathrm{TOC}}\right)$ for 53 different sediments historically contaminated with PCBs and suggested to use a coal-tar poly parameter linear-free energy relationship (pp-LFER) for estimating log $\mathrm{K}_{\text {TOC }}$ (See detailed information on log $\mathrm{K}_{\mathrm{TOC}}$ in Table SI-7). We also followed this approach to predict the partitioning behavior of PCBs between sediment and porewater by modifying equation [ (replacing $\mathrm{K}_{\mathrm{OC}}$ with $\mathrm{K}_{\mathrm{TOC}}$ ).

\section{Results and Discussion}

\section{Sediment \& Biota Characteristics}

Phytoplankton derived organic matter can be stored in the WAP shelf on the time scales of months and years, acting as a "foodbank" for benthic detritivores ${ }^{(34,53 \text {, }}$ ${ }^{54)}$. Previous studies also suggested that there was no or little variability among the organic matter in the WAP sediments, though there were seasonal pulse inputs of bloom-generated organic matter from the overlying water column ${ }^{(55)}$. This has been evidenced by previous staple isotope studies on sinking particulate organic matter (POM), sediments, and benthic biota ${ }^{(55)}$. The isotope signatures of POM and sediments showed little seasonal and inter-annual variations ${ }^{(55)}$. Thus, benthic deposit feeders were exposed to similar fresh detrital carbon year-round ${ }^{(42)}$. It is also expected that benthic detritivores showed 
relatively little temporal changes in stable isotope ratios ${ }^{(55)}$. Bulk $\delta^{15} \mathrm{~N}$ measurements showed these benthic deposit feeders were one trophic level above sediment detrital food sources ${ }^{(55)}$. The Protelpidia murrayi, Peniagone vignoni, and Bathyplotes natans are mobile, surface-deposit feeding holothurians. The Molpadia musculus is a head-down subsurface deposit feeding holothurian (or conveyor-belt feeder). According to the excess ${ }^{234}$ Th activities in gut sediments ${ }^{(34)}$, Peniagone is a more selective feeder than Bathyplotes, which in turn is more selective than Protelpidia, and than Molpadia. The former feeds selectively on high-quality fresh material at the sediment-water interface during all seasons even though labile organic matter may be less abundant during the winter. The latter ingests sediment POM less discriminately, especially the subsurface deposit feeding Molpadia which ingest particles from below the sediment-water interface ${ }^{(55)}$. The differences in feeding strategies of different holothurians were reflected in their body $\delta^{13} \mathrm{C}$ from this study, which retains the signatures of their food sources. Peniagone and Protelpidia had similar $\delta^{13} \mathrm{C}(-$ $24.45 \pm 0.20 \%$ and $-23.54 \pm 0.32 \%$ ) whereas Molpadia had a much enriched $\delta^{13} \mathrm{C}$ $\left(-18.35 \pm 0.87 \%\right.$ o ${ }^{(55)}$, probably due to its less-selective feeding activity. The total organic carbon percentages $\left(\mathrm{f}_{\mathrm{TOC}} \%\right)$ in the bottom sediments were fairly low in the five locations $(0.5-1 \%$, Table 1$)$, which were similar to $f_{\text {TOC }}$ found in the marine tidal sediments (0.04-1.71\%) on James Ross Island, Antarctica (63.8 ${ }^{\circ} \mathrm{S}$, $57.8^{\mathrm{W}}$ ), but lower compared to the $\mathrm{f}_{\mathrm{TOC}}$ in other oceanic sediments (Baltic Sea $2.4-5.9 \%)^{(40)}$. The black carbon concentrations $\left(f_{B C} \%\right)$ were independent of locations averaged around $0.1 \%$. The $\mathrm{BC}$ was composed of a higher portion of 
the TOC (BC/TOC 10-21\%) compared to other open ocean environments such as the Baltic Sea $(3-5 \%){ }^{(40)}$, but lower than sites in the tropical Atlantic Ocean (56). The relative high $\mathrm{BC} / \mathrm{TOC}$ ratios might be due to the lack of fresh organic matter input during the austral winter when the samples were collected. The BC fluxes to the sediments were highly variable among sampling locations (Table SI1a). The lowest one $\left(4.4 \mu \mathrm{g} \mathrm{cm}^{-2} \mathrm{y}^{-1}\right)$ at site 5 was comparable with other findings in offshore marine sediments (Table SI-1b). Derived BC fluxes at the other sites would require seasonal input from land-based emission sources via air and water, and could be affected by method artifacts.

The $\delta^{13} \mathrm{C}$ of the TOC showed a decreasing trend from the North (site1, $-24.9 \%$ ) towards the South (site $5,-21.9 \%$ ) with an average of $-23.4 \pm 1.1 \%$, very similar to literature values (-24 -25\% ${ }^{(55)}$. While the $\delta^{13} \mathrm{C}$ of black carbon $\left(\delta^{13} \mathrm{C}_{\mathrm{BC}}\right)$ at site 1 was more depleted $(-18.2 \%)$ which was similar to previously reported values in the Southern Ocean $(-18.6 \pm 1.4 \% \circ){ }^{(57)}, \delta^{13} \mathrm{C}_{\mathrm{BC}}$ were higher and similar at other locations $(-14.2 \pm 0.5 \%$ ) suggesting a different type of $B C$ than site 1 and a possible source of $\mathrm{C}_{4}$ plants burning. The $\delta^{13} \mathrm{C}$ labile organic carbon calculated from isotope mass balance equation was $-25.0 \pm 1.0 \%$ similar to the value of phytodetritus collected at the WAP ( -25\%०) ${ }^{(55)}$.

\section{Concentrations of PCBs \& OCPs in Sediments}

The $\Sigma_{\text {ICES }}[P C B]_{\text {sediment }}$ ranged from 0.003 to $0.35 \mathrm{ng} / \mathrm{g} \mathrm{d.w}$. with the highest concentration found at site 2. Site 2 was very close to the Palmer Station (Fig 1) where Aroclor 1260 might have been used before and an Argentine ship Bahia

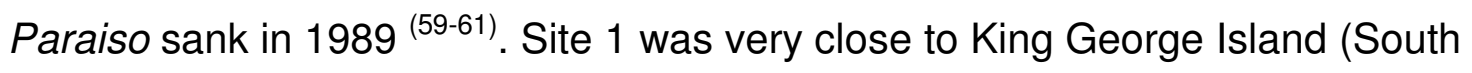


Shetland Islands) which has the highest density of scientific stations on the Antarctic Peninsula (Fig 1b). The observed $\Sigma_{\text {ICES }}[\mathrm{PCB}]_{\text {sediment }}$ distribution pattern was a resulted of the magnitude of surface pollution combined with differences in sedimentation rates. The sediment accumulation rates decreased more than ten times from the north (site 1) towards the south (site 5) on a 1000-year timescale according to ${ }^{14} \mathrm{C}$ data (Table SI-1a) ${ }^{(42)}$. Correspondingly, the PCB flux at site 5 were two orders of magnitude smaller than those at site 1-3 (Table SI-1a). The sedimentary fluxes of PCBs at site 5 was very close to those reported for Lake LV09 in Canadian Arctic (Table SI-1c). The fluxes at site 1-3 were comparable to those found in a remote lake in Rocky Mountains (US), but several orders of magnitudes smaller than others found in less remote locations (Table SI-1c). The most abundant $\mathrm{PCBs}$ were hexa-chlorinated $(\mathrm{Cl})$ congeners ranging from 40 $100 \%$ of $\Sigma_{\text {ICES }}[$ PCB], likely due to their high lipophilicity leading to their preferential binding with organic matter ( $\left.\log \mathrm{K}_{\mathrm{ow}}>7.0\right)$. HCB was the most frequently detected OCP in the sediments ranging from 0.002 to $0.13 \mathrm{ng} / \mathrm{g}$ d.w. Chlordanes and p,p'-DDE were only found at sites 1 to 3 . Similar to PCBs, the highest OCP concentrations were found at site 2. These OCPs were also frequently detected in Antarctica vegetation and soils ${ }^{(4)}$. The sedimentary fluxes of various OCPs were in line with the those found in a lake sediment core in Canadian Arctic (Table SI-1c)

Only few studies have determined the PCB and OCP concentrations in sediments in the Antarctic region. Comparison made with these studies can be found in SI on page 8 and in Table SI-4. These studies suggested anthropogenic 
activity such as scientific activities and tourism in the Antarctic are another possible source of local pollution for $\mathrm{POPs}^{(2,3,5,6,24,58)}$ in addition to long-range transport. Higher levels of contamination were always found in the vicinity of scientific stations, and the concentration levels decreased dramatically (an order of magnitude) within a relatively short distance (i.e. hundreds of meters) from the 'hotspot' sources ${ }^{(5,6)}$. Most likely, this strong gradient is due to the low temperature in the Antarctic, reducing the mobility of the POPs away from point sources.

\section{Concentrations of PCBs \& OCPs in Porewater}

The $\Sigma_{\text {ICES }}[\mathrm{PCB}]_{\text {porewater }}$ ranged from 0.06 to $3.4 \mathrm{pg} / \mathrm{L}$ with an average percentage for PCB 28 (tri-CI PCB) of $68 \%$. In contrast to the sediment concentrations, lowchlorinated PCBs were the major components of PCBs in the porewater (Table SI-2). Di- and tri-CI PCBs accounted for $71 \%$ and $21 \%$ of the total PCBs measured $\left(\Sigma_{10}[\mathrm{PCB}]\right)$. Slightly higher porewater PCB concentrations were reported in the remote Baltic marine sediments $(4.5 \pm 3.1 \mathrm{pg} / \mathrm{L})$ with a

corresponding higher average sediment concentration $(4.5 \pm 5.4 \mathrm{ng} / \mathrm{g}){ }^{(40)}$. A similar PCB congener pattern was found in the Baltic Sea study with PCB 28 accounting for $68 \pm 7 \%$ of the $\Sigma_{\mathrm{ICES}}[\mathrm{PCB}]_{\text {porewater }}$. These findings suggest that lower chlorinated congeners PCB congeners dominate the PCBs in porewater and passive samplers are only retrieving the truly dissolved phase rather than the more hydrophobic ones that are sorbed to the sediment matrix. HCB was the most abundant OCPs detected in the porewater with concentrations ranging from 
0.63 to $6.7 \mathrm{pg} / \mathrm{L}$. p,p'-DDE was detected with a decreasing trend from site 1 (1.0 $\mathrm{pg} / \mathrm{L})$ through $3(0.11 \mathrm{pg} / \mathrm{L})$ with an average concentration of $0.49 \mathrm{pg} / \mathrm{L}$. Chlordanes were only detected at a couple sites with low average concentrations (CC, $0.60 \mathrm{pg} / \mathrm{L}, \mathrm{TC}, 1.2 \mathrm{pg} / \mathrm{L})$.

Benthic biota that live at the sediment-water interface are exposed to the contaminants in both porewater and overlying water column. Ideally, concentrations in both matrixes are needed to assess their body burdens. We are not aware of measurements for PCBs and OCPs in the water column near the Palmer LTER region as part of this or other studies. There have been measurements of PCBs and OCPs in the Ross Sea from Italian Antarctic expeditions. A depth profile of PCB concentrations was reported in the Ross Sea from the 2002-2003 expedition, with deep water $(>170 \mathrm{~m})$ concentrations about two times higher than those in the shallow water (30 and $60 \mathrm{~m}, 45 \mathrm{pg} / \mathrm{L}){ }^{(8)}$. It was argued that modified circumpolar deep water carried higher levels of PCBs from the Pacific Ocean ${ }^{(8)}$. The XIX Italian Antarctic Oceanographic cruise (Dec 2003 Jan 2004) reported a HCB concentration of $6.33 \pm 4.38(1.72-16.2) \mathrm{pg} / \mathrm{L}^{(8)}$. However, the highest $\Sigma_{\text {ICES }}[\mathrm{PCB}]$ reported in recent cruises in the South Pacific was $7.8 \mathrm{pg} / \mathrm{L}$ and $[\mathrm{HCB}]$ was $0.8 \mathrm{pg} / \mathrm{L}^{(10)}$. The higher concentration at depth could also result from the remineralization of sinking particulate organic matter (POC) at deeper water and release of bound POPs back to water column ${ }^{(62)}$. A study conducted at the remote Baltic Sea measured sediment porewater and overlying water column concentrations simultaneously ${ }^{(40)}$. It suggested that less hydrophobic PCBs (PCB 28 through 153) had a higher water column 
concentration than porewater, whereas more hydrophobic ones (PCB 138 and 180) had similar concentrations in both water phases. Even though the porewater concentrations of POPs were low or below detection at our sampling sites 4 and 5 in the Palmer LTER grids, PCBs (up to congener no. 101) and OCPs (i.e. HCB, p,p'-DDE, and chlordanes) with log $\mathrm{K}_{\mathrm{ow}}<7$ could have a higher water column concentration than that in porewater based upon the Baltic Sea results.

\section{Concentrations of PCBs \& OCPs in Biota}

The concentrations of PCBs and OCPs were normalized to lipid percentage ( $f_{\text {lipid }}$ \%). Lipids are considered as the major accumulation compartments in biota for lipophilic PCBs and OCPs ${ }^{(48)}$. Lipid-normalized concentrations ([PCB] $]_{\text {lipid }}$ \& $[\mathrm{OCP}]_{\text {lipid }}$ ) enable comparison of contaminant levels in various biota. The lowest $\Sigma_{\text {ICES }}[P C B]_{\text {lipid }}(0.84 \mathrm{ng} / \mathrm{g}$ lipid) was found in the Molpadia from site 1 , which is the only subsurface deposit feeder species collected. It is less selective about its food resource than other species reported here. The more selective surface deposit feeder Bathyplotes found at the same site had a higher $\Sigma_{I C E S}[P C B]$ lipid of $2.7 \mathrm{ng} / \mathrm{g}$ lipid. This may result from the different feeding strategy and exposure to contaminants in the overlying water column. The highest concentration of $\Sigma_{\text {ICES }}[P C B]_{\text {lipid }}$ was found in the Protelpidia (10.3 ng/g lipid) from site 2 where highest $\Sigma_{\text {ICES }}[P C B]_{\text {sediment }}$ was detected. The dominant PCBs in these biota samples were hexa-Cl congeners (PCB 138 and 153) accounting for an average of $49 \%$ in the detected $\Sigma_{\text {ICES }}[P C B]_{\text {lipid. }}$ Next came penta-Cl congeners (PCB 101 and 118 ) which made up of $24 \%$ of the total $\Sigma_{\text {ICES }}[P C B]$ lipid on average. To further compare the congener profiles in various holothurians at different sites, a 
hierarchical cluster analysis was conducted using a similarity profile test (SIMPROF). The details of this test can be found in SI on page 9.

HCB $(0.87 \pm 0.34 \mathrm{ng} / \mathrm{g}$ lipid), TC $(0.17 \pm 0.12 \mathrm{ng} / \mathrm{g}$ lipid $), \mathrm{CC}(0.13 \pm 0.06 \mathrm{ng} / \mathrm{g}$ lipid $)$, and $p, p^{\prime}-D D E(0.26 \pm 0.15 \mathrm{ng} / \mathrm{g}$ lipid) were detected in all of the holothurians with smaller intra-space and species differences in concentrations compared to PCBs. Although there have been several studies on POPs in Antarctic pelagic food web species ${ }^{(24,29,30,33)}$, this is the first comprehensive report on PCB and OCP concentrations in benthic holothurians at the Western Antarctic Peninsula. Comparisons on concentrations were thus made between holothurians and other species on the similar trophic level in the Antarctic food web. The sinking particulate organic matter (POM) at the WAP was dominated by quickly-sinking diatom aggregates (phytodetritus) and fecal pellets of krill (Euphausia superba) ${ }^{(63,64)}$. These sinking POM are the major food source for benthic holothurians. Thus, the krill and benthic holothurians are considered to be on a similar trophic level. In addition, $\delta^{15} \mathrm{~N}$ values were similar in the krill $(11.2 \pm 0.5 \% \circ)^{(65)}$ and benthic holothurians $\left(8.0-10.2 \% \circ{ }^{(55)} . \delta^{15} \mathrm{~N}\right.$ has been used to characterize trophic levels with levels of POPs in organisms ${ }^{(66)}$. Concentrations of PCBs and OCPs were comparable to other lipid-normalized low trophic level biota concentrations in the Antarctic $(24,27,29,30,33)$. Detailed comparison can be found in SI on page 10 (Table SI-5)

\section{Partitioning between Sediments and Porewater}

Predicted partitioning coefficients based on the classic model (equation $\square$ ) which considers absorption into organic carbon $(\mathrm{OC})$ dominating the partitioning 
behavior of hydrophobic POPs in the sediments, underestimated the distribution of all PCB congeners by 10-100 times (Fig 2A). Several previous studies have found that observed distribution coefficients $\left(K_{D}\right)$ can not be explained by partitioning into $O C$ alone ${ }^{(47,67,68)}$, suggesting there was an additional sediment fraction present (i.e., BC or another recalcitrant carbon fraction) with a higher sorption capacity of hydrophobic POPs than $\mathrm{OC}{ }^{(48)}$. The Freundlich distribution model (Equation $\square$ ) has been employed to account for both $\mathrm{OC}$ and BC sorption of POPs in the sediments. The Freundlich exponent $\mathrm{n}$ is determined by both the characterization of the sorption sites on $\mathrm{BC}$ as well as the hydrophobic structure of POPs ${ }^{(69,70)}$, which was taken a value of 0.7 from previous studies ${ }^{(48)} . \mathrm{K}_{\mathrm{BC}}$ LFER relationship was chosen from Koelmans et al ${ }^{(70)}$.

$$
\log \mathrm{K}_{\mathrm{BC}}=1.1016^{*} \log \mathrm{K}_{\mathrm{OW}}+0.2469
$$

Other reported $K_{B C} L F E R$ relationships generated very similar $K_{B C}$ values with differences less than $0.3 \log$ unit ${ }^{(35,71)}$. With the above chosen parameters, the dual-mode model (Equation [) produced a better prediction (less than a factor of 10 from the observed $K_{D}$ values, Figure $2 B$ ) than the model with $\mathrm{OC}$ alone (Figure 2A). This probably means that the value of Freundlich exponent $n$ needs to be adjusted based on the composition of different black carbons. Since BC is composed of a mixture of various reduced and aromatic $\mathrm{OC}, \mathrm{n}$ could vary between different locations. The $\delta^{13} \mathrm{C}$ of black carbon revealed that the black carbon at site 1 were different from site 2 and 3 (Table 1 ), which probably will have different $n$ values. When we chose smaller $n$ values $(0.68$ for site $1,0.57$ for 
site 2, and 0.58 for site3), the predictions were less a factor of 3 for PCBs compared to observed values (Fig SI-4).

The sorption mechanisms for POPs to BC is an adsorptive process and nonlinearly depends on the porewater concentration ([POP $]_{\text {porewater }}$ ), whereas the absorption into OC represents a linear process. The lower the porewater concentration is, the larger the contribution of $\mathrm{BC}$ to the overall partitioning process ${ }^{(37)}$. In this study, the $[\mathrm{POP}]_{\text {porewater }}$ for both PCBs and OCPs were on the level of sub-picogram per liter which resulted in a large portion of the PCBs and OCPs being adsorbed onto BC. For very hydrophobic hexa-CI PCBs up to $94 \%$ were sorbed with BC, even for less hydrophobic di-CI PCBs (PCB 8) $63 \%$ of them were affiliated with $\mathrm{BC}$ according to calculation obtained from Equation 0. Thus, the majority of PCBs and OCPs were not available as part of the organic carbon pool due to their sorption with $\mathrm{BC}$. This greatly reduced the porewater concentrations of PCBs and OCPs in the sediments and resulted in reduced bioavailability of POPs through passive exposure at these locations. The one-carbon model (TOC) approach can also generate a better prediction of partitioning behavior of PCBs between sediment and porewater than $\mathrm{OC}$ alone (Figure $2 \mathrm{~A} \& \mathrm{C})$. We chose the median values of the $\log \mathrm{K}_{\text {TOC }}$ compiled by Hawthorne et al ${ }^{(36)}$ from 53 different sediments historically contaminated with PCBs and plotted them against observed $K_{D}$ values (Figure $2 C$ ). The $f_{\text {TOC }} K_{\text {TOC }}$ predictions fell within one order of magnitude with the observed $K_{D}$. Importantly, both the two-carbon and one-carbon model predicted the partitioning coefficients of PCBs within a factor of ten from the observed ones. The one-carbon model 
tends to underestimate the $K_{D}$ values for high-chlorinated PCBs and overestimate those for low-chlorinated PCBs, whereas the two-carbon $(\mathrm{OC}$ and $B C)$ generally predicts lower $K_{D}$ values compared to observed ones. The main advantage of the TOC-model is that only 1 paramater; only $\mathrm{f}_{\mathrm{TOC}}$ is needed to make a decent prediction of overall partitioning. On the other hand, there are mechanistic advantages to the OC-BC model. First of all, our measurement (see QA/QC in SI for details) and other studies did find black carbon exist in the sediments in Antarctic ${ }^{(72)}$, which may be resulted from local activities and long-range transport. Geochemically speaking, the existence of 2 carbon pools (organic vs black carbon) is widely accepted, though the exact cutoff of the two pools is under debate ${ }^{(73)}$. Second, the sorption strength to OC (adsorption) and BC (adsorption) have been measured independently in laboratory and field studies ${ }^{(47)}$. In contrast, there is no lab/field measurement of a coal tar type of TOC to our best knowledge. Yet, the TOC model works surprisingly well considering it covered a wide range of different sediments.

\section{Partitioning between Biota and Porewater}

Benthic holothurians are deposit feeders which take up POPs passively through physical contact with porewater (bioconcentration) as well as actively through ingestion of sediment particles. The bioaccumulation of POPs by deposit feeder oligochaete can be explained by equilibrium partitioning of POPs between porewater and the lipids of the oligochaete according to Kraaij et al ${ }^{(74)}$ regardless of their uptaking pathway. Following their approach, the lipid-porewater partitioning coefficients ( $\mathrm{K}_{\text {lipid }}$ ) of benthic holothurians were calculated based on 
equation $\square$ and plotted against with corresponding Kow (Fig. 3). Regression analysis suggested the obtained relationships were significantly linear; the standard errors were much smaller than the slopes (Table SI-5). In other words, the bioaccumulation of PCBs up to log $\mathrm{K}_{\mathrm{O}} \mathrm{P} 7.7$ in our sampling sites at WAP can be described by equilibrium partitioning between the lipids of benthic holothurians and porewater. The $\mathrm{K}_{\text {lipid }}$ equals the bioconcentration factor in this case. The body burden of PCBs in sediment dwelling holothurians can be estimated on the basis of PCB concentrations in porewater and their bioconcentration factors. Statistical analysis on regressions revealed that obtained $\mathrm{K}_{\text {lipid }}-\mathrm{K}_{\text {ow }}$ relationships of site 1 Molpadia and Bathyplotes were not significantly different from each other $(p<0.05)$ but were significantly different from Protelpedia at Site 2 . The difference could be attributed to the fact that they were different biota species with different feeding strategies (sub-surface vs surface) and different food selectivity, which probably lead to different lipid composition in their bodies. Previous study indicated different lipid pools (storage vs. membrane) can have distinguished $\mathrm{K}_{\text {lipid }}{ }^{(75,76)}$. The obtained $\mathrm{K}_{\text {lipid }}-\mathrm{K}_{\text {ow }}$ relationships for Protelpedia at site 2 and 3 were not significantly different from each other (Fig 3). The regression of average $\mathrm{K}_{\text {lipid }}-\mathrm{K}_{\text {ow }}\left(\log \mathrm{K}_{\text {lipid }}=0.949^{*} \mathrm{~K}_{\text {ow }}+0.06\right)$ was very close to literature values (Table SI-4).

\section{Implications}

Our results suggest that recalcitrant carbon (possibly black carbon) reduces the availability of sedimentary POPs even in the most remote region of the planet. Partitioning model developed including both organic carbon and black carbon in 
impacted sediments from the northern hemisphere gave good results for predicting porewater concentrations of POPs in the remote region. Using the recently postulated one-carbon (TOC) model resulted in predictions that were similarly within an order of magnitude of observed partitioning coefficient $\left(\mathrm{K}_{\mathrm{D}}\right)$ values. The partitioning behavior of various chlorinated organic pollutants into benthic invertebrates was very similar between our remote sites and impacted sites elsewhere.

There is evidence of more and warmer Circumpolar Deep Water intrusion on the WAP continental shelf ${ }^{(77)}$, which could bring not only anthropogenic pollutants to the WAP in the future, but also nutrients to the surface ocean through upwelling which could increase surface primary production and enhance sedimentation. The increased amount of sinking organic matter would bring more lipophilic POPs from the surface ocean to the shelf sediments. The increased temperature in the projected climate change scenario could also aid to mobilize the previously deposited POPs in the vicinity of scientific research stations throughout the Antarctica by water current and atmospheric transport.

\section{Acknowledgements}

This research is supported by the National Science Foundation under OPP, ARRA No ANT-0838860 and the Antarctic Organisms and Ecosystems Program in the Antarctic Sciences Division of NSF. LZ acknowledges a travel award from the National Science Foundation Experimental Program to Stimulate Competitive Research (EPSCoR) Cooperative Agreement \#EPS-1004057 (EPSCoR Grant 
No. 0554548). Thanks to Dr. Mark Cantwell (U.S. EPA) for help with black carbon and stable isotope measurements.

\section{Supporting Information Available}

Additional information on results comparison, figures, and tables were included in the Supporting Information section. This information is available free of charge via the Internet at http://pubs.acs.org/. 
Table 1. Sampling locations, sediments and benthic biota characteristics. Sites 1 to 5 in this study are corresponding to site $A A, B, E, F$, and $G$ in the FOODBANCS-2 project ${ }^{(42)}$.

\begin{tabular}{|c|c|c|c|c|c|c|}
\hline & 1 & 2 & 3 & 4 & 5 \\
\hline $\mathrm{La}$ & titude & -63.05 & -64.80 & -65.98 & -66.98 & -68.13 \\
\hline & -61.60 & -65.33 & -67.28 & -69.72 & -71.00 \\
\hline Samp & ling date & Jul-25-2008 & Jul-28-2008 & Jul-20-2008 & Jul-19-2008 & $\begin{array}{l}\text { Jul-15- } \\
2008\end{array}$ \\
\hline \multicolumn{2}{|c|}{ Depth (m) } & 578 & 578 & 597 & 590 & 582 \\
\hline \multirow{6}{*}{ Sediments } & $\mathrm{f}_{\mathrm{TOC}}(\%)$ & $0.46 \%$ & $0.87 \%$ & $1.02 \%$ & $0.62 \%$ & $0.55 \%$ \\
\hline & $\mathrm{f}_{\mathrm{BC}}(\%)$ & $0.094 \%$ & $0.104 \%$ & $0.102 \%$ & $0.099 \%$ & $0.112 \%$ \\
\hline & $\mathrm{BC} / \mathrm{TOC}(\%)$ & $19.95 \%$ & $12.25 \%$ & $10.21 \%$ & $16.21 \%$ & $21.47 \%$ \\
\hline & $\delta^{13} \mathrm{C}$ TOC & -24.9 & -24.0 & -23.3 & -23.1 & -21.9 \\
\hline & $\delta^{13} \mathrm{CBC}$ & -18.2 & -14.7 & -14.1 & -13.6 & -14.3 \\
\hline & $\delta^{13} \mathrm{C} \mathrm{OC}$ & -26.5 & -25.4 & -24.3 & -24.9 & -24.0 \\
\hline \multirow[t]{2}{*}{ Biota } & species & $\begin{array}{l}\text { Molpadia Bathyplote } \\
\text { sub- } \\
\text { surface }\end{array}$ & \multicolumn{3}{|c|}{ surface deposit feeding holothurians } & Peniagone \\
\hline & lipid (\%) & $4.5 \%$ & $3.3 \%$ & $2.8 \%$ & $2.6 \%$ & $3.1 \%$ \\
\hline
\end{tabular}




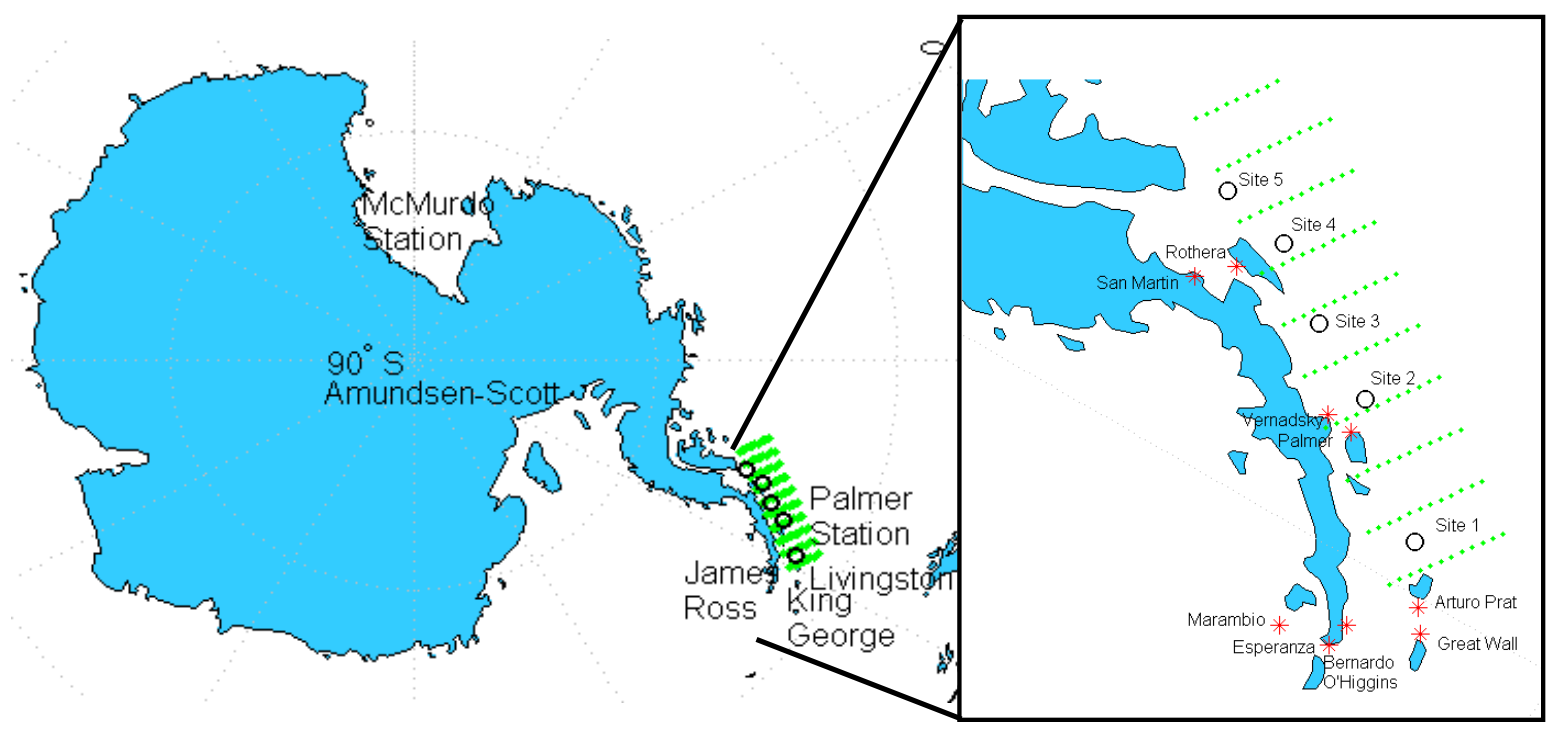

Figure 1. A. Map of Antarctic with Major Scientific Research Stations. B. Sampling Sites 1-5 (O). Selected Scientific Research Stations ( $\left.{ }^{*}\right)$. Palmer Long Term Ecological Research (LTER) grids ( ${ }^{\circ}$. Sites 1 to 5 in this study are corresponding to site AA, B, E, F, and G in the FOODBANCS-2 project ${ }^{(42)}$ 

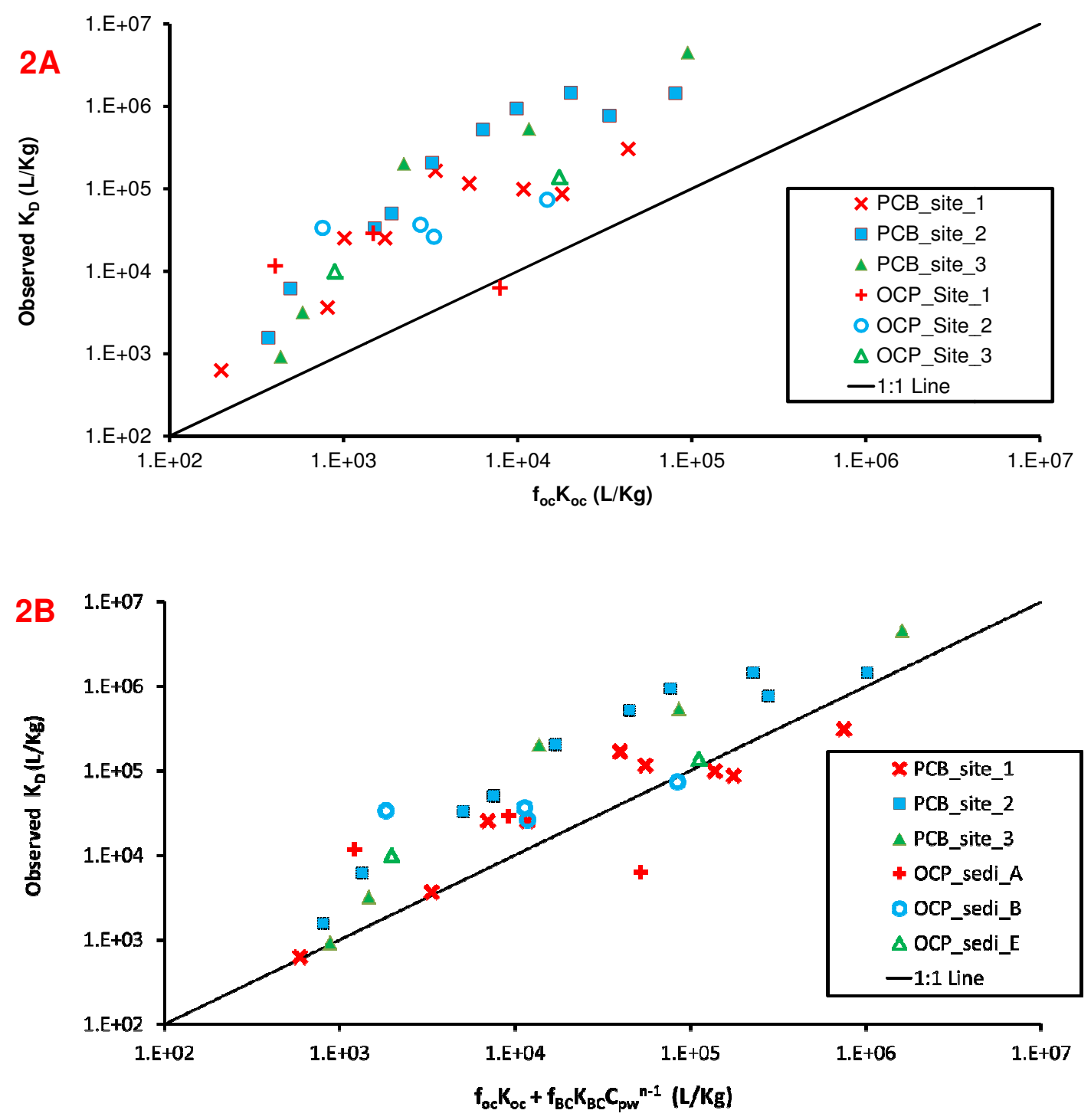

Figure 2. Observed distribution coefficients $\left(\mathrm{K}_{\mathrm{D}}\right)$ compared to predicted partitioning based on equations ( $\square$ and $\square$ ) in sediments from site 1-3. The black line represents $1: 1 \mathrm{log} / \mathrm{log}$ relationship. A. predicted values derived from equation $\square$ when organic carbon was considered as the solely partitioning medium in the sediments. B. predicted values derived from equation $\square$ when both organic carbon and black carbon were taken into account for controlling the partitioning process. $\mathrm{n}$ was chosen as 0.7. C. predicted values derived from modified equation? with Log $\mathrm{K}_{\mathrm{TOC}}$ chosen from Hawthorne et al (2011) 

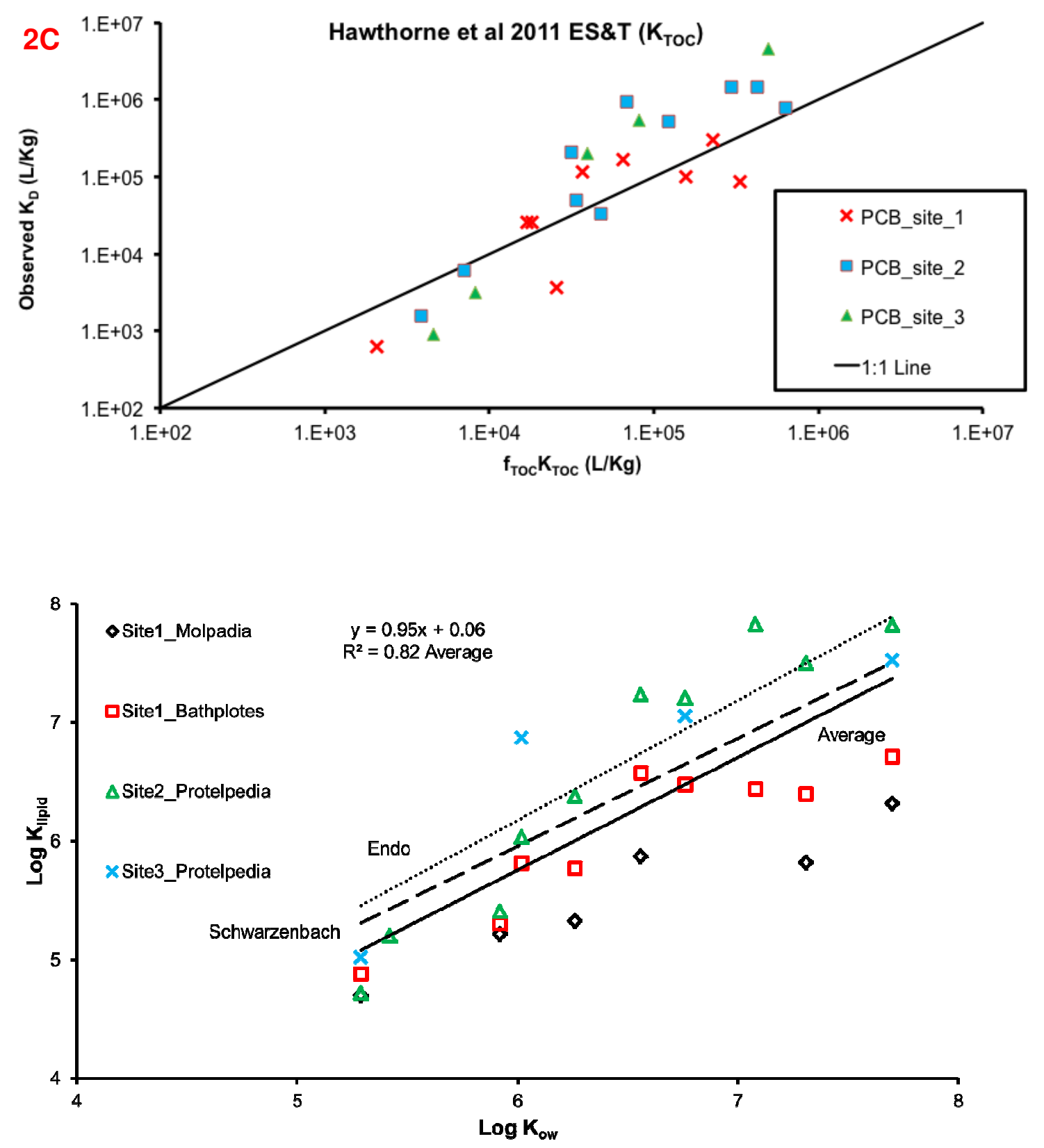

Figure 3 Regressions for $\mathrm{K}_{\text {lipid }}-\mathrm{K}_{\text {ow }}$ relationships for benthic holothurians at different sites. Average $\mathrm{K}_{\text {lipid }}$ values were also plotted against $\mathrm{K}_{\text {ow }}$ (blackline) with a linear relationship of $\log \mathrm{K}_{\text {lipid }}=0.95^{\star} \log \mathrm{K}_{\mathrm{ow}}+0.06$. Literature reported relationships were also plotted for comparison; Endo et al $2011(\cdots . . . *)$ and Schwarzenbach et al 2003 (------). 


\section{References}

\section{References}

1. Lovenduski, N.S. and Ito, T. The future evolution of the Southern Ocean CO2 sink. $J$. Mar. Res. 2009, 67, 597-617.

2. Klánová, J.; Matykiewiczová, N.; Máčka, Z.; Prošek, P.; Láska, K.; Klán, P. Persistent organic pollutants in soils and sediments from James Ross Island, Antarctica.

Environmental Pollution 2008, 152, 416-423.

3. Nash, S.B. Persistent organic pollutants in Antarctica: current and future research priorities. J. Environ. Monit. 2011, 13, 497-504.

4. Cabrerizo, A.; Dachs, J.; Barcelo, D.; Jones, K.C. Influence of Organic Matter Content and Human Activities on the Occurrence of Organic Pollutants in Antarctic Soils, Lichens, Grass and Mosses. Environ. Sci. Technol. 2012, 46, 1396-1405.

5. Negri, A.; Burns, K.; Boyle, S.; Brinkman, D.; Webster, N. Contamination in sediments, bivalves and sponges of McMurdo Sound, Antarctica. Environmental Pollution 2006, 143, 456-467.

6. Kennicutt II, M.; McDonald, S.; Sericano, J.; Boothe, P.; Oliver, J.; Safe, S.; Presley, B.; Liu, H.; Wolfe, D.; Wade, T. Human contamination of the marine environmentArthur Harbor and McMurdo Sound, Antarctica. Environ. Sci. Technol. 1995, 29, 12791287.

7. Tanabe, S.; Hidaka, H.; Tatsukawa, R. PCBs and chlorinated hydrocarbon pesticides in Antarctic atmosphere and hydrosphere. Chemosphere 1983, 12, 277-288.

8. Fuoco, R.; Giannarelli, S.; Wei, Y.; Ceccarini, A.; Abete, C.; Francesconi, S.; Termine, M. Persistent organic pollutants (POPs) at Ross Sea (Antarctica). Microchemical Journal 2009, 92, 44-48.

9. R Rintoul, S.; W Hughes, C.; Olbers, D. .6 The antarctic circumpolar current system. International Geophysics 2001, 77, 271-XXXVI.

10. Zhang, L. and Lohmann, R. Cycling of PCBs and HCB in the surface ocean-lower atmosphere of the open Pacific. Environ. Sci. Technol. 2010, 44, 3832-3838.

11. Matsumoto, K. Radiocarbon-based circulation age of the world oceans. J.Geophys.Res 2007, 112, 
12. Broecker, W.S.; Blanton, S.; Smethie Jr, W.M.; Ostlund, G. Radiocarbon decay and oxygen utilization in the deep Atlantic Ocean. Global Biogeochem. Cycles 1991, 5, 87117.

13. Speich, S.; Blanke, B.; Cai, W. Atlantic meridional overturning circulation and the Southern Hemisphere supergyre. Geophys. Res. Lett. 2007, 34, L23614.

14. Iudicone, D.; Madec, G.; McDougall, T.J. Water-mass transformations in a neutral density framework and the key role of light penetration. J. Phys. Oceanogr. 2008, 38, 1357-1376.

15. Tatton, J. and Ruzicka, J. Organochlorine pesticides in Antarctica. Nature 1967, 215, 346-348.

16. Risebrough, R.; Walker, W.; Schmidt, T.; De Lappe, B.; Connors, C. Transfer of chlorinated biphenyls to Antarctica. 1976, 264, 738 - 739

17. Bidleman, T.F.; Walla, M.D.; Roura, R.; Carr, E.; Schmidt, S. Organochlorine pesticides in the atmosphere of the Southern Ocean and Antarctica, January-March, 1990. Mar. Pollut. Bull. 1993, 26, 258-262.

18. Dickhut, R.M.; Cincinelli, A.; Cochran, M.; Ducklow, H.W. Atmospheric concentrations and air-water flux of organochlorine pesticides along the western Antarctic Peninsula. Environ. Sci. Technol. 2005, 39, 465-470.

19. Montone, R.; Taniguchi, S.; Weber, R. PCBs in the atmosphere of King George Island, Antarctica. Sci. Total Environ. 2003, 308, 167-173.

20. Kallenborn, R.; Oehme, M.; Wynn-Williams, D.D.; Schlabach, M.; Harris, J. Ambient air levels and atmospheric long-range transport of persistent organochlorines to Signy Island, Antarctica. Sci. Total Environ. 1998, 220, 167-180.

21. Cincinelli, A.; Martellini, T.; Del Bubba, M.; Lepri, L.; Corsolini, S.; Borghesi, N.; King, M.D.; Dickhut, R.M. Organochlorine pesticide air-water exchange and bioconcentration in krill in the Ross Sea. Environmental Pollution 2009, 157, 2153-2158.

22. Fuoco, R.; Colombini, M.P.; Ceccarini, A.; Abete, C. Polychlorobiphenyls in Antarctica. Microchemical journal 1996, 54, 384-390.

23. Montone, R.C.; Taniguchi, S.; Weber, R.R. Polychlorinated biphenyls in marine sediments of Admiralty bay, King George Island, Antarctica. Mar. Pollut. Bull. 2001, 42, 611-614.

24. Bengtson Nash, S.; Poulsen, A.; Kawaguchi, S.; Vetter, W.; Schlabach, M. Persistent organohalogen contaminant burdens in Antarctic krill (Euphausia superba) from the eastern Antarctic sector: A baseline study. Sci. Total Environ. 2008, 407, 304-314. 
25. Larsson, P.; Järnmark, C.; Södergren, A. PCBs and chlorinated pesticides in the atmosphere and aquatic organisms of Ross Island, Antarctica. Mar. Pollut. Bull. 1992, 25, 281-287.

26. Corsolini, S.; Kannan, K.; Imagawa, T.; Focardi, S.; Giesy, J.P. Polychloronaphthalenes and other dioxin-like compounds in Arctic and Antarctic marine food webs. Environ. Sci. Technol. 2002, 36, 3490-3496.

27. Corsolini, S.; Covaci, A.; Ademollo, N.; Focardi, S.; Schepens, P. Occurrence of organochlorine pesticides (OCPs) and their enantiomeric signatures, and concentrations of polybrominated diphenyl ethers (PBDEs) in the Adelie penguin food web, Antarctica. Environmental pollution 2006, 140, 371-382.

28. Corsolini, S.; Romeo, T.; Ademollo, N.; Greco, S.; Focardi, S. POPs in key species of marine Antarctic ecosystem. Microchemical journal 2002, 73, 187-193.

29. Chiuchiolo, A.L.; Dickhut, R.M.; Cochran, M.A.; Ducklow, H.W. Persistent organic pollutants at the base of the Antarctic marine food web. Environ. Sci. Technol. 2004, 38, 3551-3557.

30. Geisz, H.N.; Dickhut, R.M.; Cochran, M.A.; Fraser, W.R.; Ducklow, H.W. Melting Glaciers: A Probable Source of DDT to the Antarctic Marine Ecosystem. Environ. Sci. Technol. 2008, 42, 3958-3962.

31. Weber, K. and Goerke, H. Persistent organic pollutants (POPs) in antarctic fish: levels, patterns, changes. Chemosphere 2003, 53, 667-678.

32. Weber, K. and Goerke, H. Organochlorine compounds in fish off the Antarctic Peninsula. Chemosphere 1996, 33, 377-392.

33. Goerke, H.; Weber, K.; Bornemann, H.; Ramdohr, S.; Plotz, J. Increasing levels and biomagnification of persistent organic pollutants (POPs) in Antarctic biota. Mar. Pollut. Bull. 2004, 48, 295-302.

34. Smith, C.R.; Mincks, S.; DeMaster, D.J. A synthesis of bentho-pelagic coupling on the Antarctic shelf: food banks, ecosystem inertia and global climate change. Deep Sea Research Part II: Topical Studies in Oceanography 2006, 53, 875-894.

35. Werner, D.; Hale, S.E.; Ghosh, U.; Luthy, R.G. Polychlorinated Biphenyl Sorption and Availability in Field-Contaminated Sediments $\dagger$. Environ. Sci. Technol. 2009, 44, 2809-2815.

36. Hawthorne, S.B.; Grabanski, C.B.; Miller, D.J.; Arp, H.P. Improving Predictability of Sediment-Porewater Partitioning Models using Trends Observed with PCBContaminated Field Sediments (new title for revised version). Environ. Sci. Technol. 2011, 45, 7365-7371 
37. Lambert, M.K.; Friedman, C.; Luey, P.; Lohmann, R. Role of black carbon in the sorption of polychlorinated dibenzo-p-dioxins and dibenzofurans at the Diamond Alkali Superfund site, Newark Bay, New Jersey. Environ. Sci. Technol. 2010, 45, 4331-4338

38. Lohmann, R.; Burgess, R.M.; Cantwell, M.G.; Ryba, S.A.; MacFarlane, J.K.; Gschwend, P.M. Dependency of polychlorinated biphenyl and polycyclic aromatic hydrocarbon bioaccumulation in Mya arenaria on both water column and sediment bed chemical activities. Environmental Toxicology and Chemistry 2004, 23, 2551-2562.

39. Lohmann, R.; MacFarlane, J.; Gschwend, P. Importance of black carbon to sorption of native PAHs, PCBs, and PCDDs in Boston and New York harbor sediments. Environ. Sci. Technol. 2005, 39, 141-148.

40. Cornelissen, G.; Wiberg, K.; Broman, D.; Arp, H.P.H.; Persson, Y.; Sundqvist, K.; Jonsson, P. Freely dissolved concentrations and sediment-water activity ratios of PCDD/Fs and PCBs in the open Baltic Sea. Environ. Sci. Technol. 2008, 42, 8733-8739.

41. Waters, K.J. and Smith, R.C. Palmer LTER: A sampling grid for the Palmer LTER program. Antarct. J. U. S. 1992, 27, 236-239.

42. DeMaster, D.; Smith, C.; Thomas, C. Trends in biogeochemical tracers along a climate-sensitive transect on the west Antarctic peninsula shelf: results from FOODBANCS-2. 2012,

43. Adams, R.G.; Lohmann, R.; Fernandez, L.A.; MacFarlane, J.K.; Gschwend, P.M. Polyethylene devices: Passive samplers for measuring dissolved hydrophobic organic compounds in aquatic environments. Environ. Sci. Technol. 2007, 41, 1317-1323.

44. Friedman, C.L.; Cantwell, M.G.; Lohmann, R. Passive sampling provides evidence for Newark Bay as a source of polychlorinated dibenzo-p-dioxins and furans to the New York/New Jersey, USA, atmosphere. Environmental Toxicology and Chemistry 2012,

45. Xia, G. Sorption Behavior of Nonpolar Organic Chemicals on Natural Sorbents. John Hopkins University, dissertation 1998,

46. Allen-King, R.M.; Grathwohl, P.; Ball, W.P. New modeling paradigms for the sorption of hydrophobic organic chemicals to heterogeneous carbonaceous matter in soils, sediments, and rocks. Adv. Water Resour. 2002, 25, 985-1016.

47. Accardi-Dey, A.M. and Gschwend, P.M. Reinterpreting literature sorption data considering both absorption into organic carbon and adsorption onto black carbon. Environ. Sci. Technol. 2003, 37, 99-106.

48. Schwarzenbach, R.P.; Gschwend, P.M.; Imboden, D.M. Environmental Organic Chemistry, Second Edition. John Wiley \& Sons, Inc.: Hoboken, NJ, USA, 2003; pp. 1328. 
49. Arp, H.P.H.; Breedveld, G.D.; Cornelissen, G. Estimating the in situ sedimentporewater distribution of PAHs and chlorinated aromatic hydrocarbons in anthropogenic impacted sediments. Environ. Sci. Technol. 2009, 43, 5576-5585.

50. Nguyen, T.H.; Goss, K.U.; Ball, W.P. Polyparameter linear free energy relationships for estimating the equilibrium partition of organic compounds between water and the natural organic matter in soils and sediments. Environ. Sci. Technol. 2005, 39, 913-924.

51. van Noort, P. Estimation of amorphous organic carbon/water partition coefficients, subcooled aqueous solubilities, and $<\mathrm{i}>\mathrm{n}$-octanol/water distribution coefficients of alkylbenzenes and polycyclic aromatic hydrocarbons. Chemosphere 2009, 74, 1018-1023.

52. van Noort, P.C.M.; Haftka, J.J.H.; Parsons, J.R. Updated Abraham solvation parameters for polychlorinated biphenyls. Environmental Science and Technology 2010, 44, 7037-7042.

53. Mincks, S.L.; Smith, C.R.; DeMaster, D.J. Persistence of labile organic matter and microbial biomass in Antarctic shelf sediments: evidence of a sediment food bank. Mar. Ecol. Prog. Ser. 2005, 300, 3-19.

54. Smith, C.R.; Mincks, S.; DeMaster, D.J. The FOODBANCS project: Introduction and sinking fluxes of organic carbon, chlorophyll-a and phytodetritus on the western Antarctic Peninsula continental shelf. Deep Sea Research Part II: Topical Studies in Oceanography 2008, 55, 2404-2414.

55. Mincks, S.L.; Smith, C.R.; Jeffreys, R.M.; Sumida, P.Y.G. Trophic structure on the West Antarctic Peninsula shelf: Detritivory and benthic inertia revealed by [delta] $13 \mathrm{C}$ and [delta] 15N analysis. Deep Sea Research Part II: Topical Studies in Oceanography 2008, 55, 2502-2514.

56. Lohmann, R.; Bollinger, K.; Cantwell, M.; Feichter, J.; Fischer-Bruns, I.; Zabel, M. Fluxes of soot black carbon to South Atlantic sediments. Global Biogeochem. Cycles 2009, 23, GB1015.

57. Masiello, C. and Druffel, E. Black carbon in deep-sea sediments. Science 1998, 280, 1911-1913.

58. Hale, R.C.; Kim, S.L.; Harvey, E.; La Guardia, M.J.; Mainor, T.M.; Bush, E.O.; Jacobs, E.M. Antarctic research bases: local sources of polybrominated diphenyl ether (PBDE) flame retardants. Environ. Sci. Technol. 2008, 42, 1452-1457.

59. Bargagli, R. Environmental contamination in Antarctic ecosystems. Sci. Total Environ. 2008, 400, 212-226. 
60. Kennicutt, M.C.; Sweet, S.T.; Fraser, W.R.; Stockton, W.L.; Culver, M. Grounding of the Bahia Paraiso at Arthur Harbor, Antarctica. 1. Distribution and fate of oil spill related hydrocarbons. Environ. Sci. Technol. 1991, 25, 509-518.

61. Kennicutt, M.; McDonald, T.; Denoux, G.; McDonald, S. Hydrocarbon contamination on the Antarctic Peninsula: I. Arthur harbor-Subtidal sediments. Mar. Pollut. Bull. 1992, 24, 499-506.

62. Hargrave, B.T.; Vass, W.P.; Erickson, P.E.; Fowler, B.R. Atmospheric transport of organochlorines to the Arctic Ocean. Tellus, Series B-Chemical and Physical Meteorology 1988, 40, 480-493.

63. Buesseler, K.O.; McDonnell, A.M.P.; Schofield, O.M.E.; Steinberg, D.K.; Ducklow, H.W. High particle export over the continental shelf of the west Antarctic Peninsula. Geophys. Res. Lett. 2010, 37, L22606.

64. McDonnell, A.M.P. and Buesseler, K.O. Variability in the average sinking velocity of marine particles. Limnol. Oceanogr. 2010, 55, 2085.

65. Jarman, W.M.; Hobson, K.A.; Sydeman, W.J.; Bacon, C.E.; McLaren, E.B. Influence of trophic position and feeding location on contaminant levels in the Gulf of the Farallones food web revealed by stable isotope analysis. Environ. Sci. Technol. 1996, 30, 654-660.

66. Fisk, A.T.; Hobson, K.A.; Norstrom, R.J. Influence of chemical and biological factors on trophic transfer of persistent organic pollutants in the Northwater Polynya marine food web. Environ. Sci. Technol. 2001, 35, 732-738.

67. Cornelissen, G.; Gustafsson, Ö; Bucheli, T.D.; Jonker, M.T.O.; Koelmans, A.A.; van Noort, P.C.M. Extensive sorption of organic compounds to black carbon, coal, and kerogen in sediments and soils: Mechanisms and consequences for distribution, bioaccumulation, and biodegradation. Environ. Sci. Technol. 2005, 39, 6881-6895.

68. Jonker, M.T.O. and Koelmans, A.A. Sorption of polycyclic aromatic hydrocarbons and polychlorinated biphenyls to soot and soot-like materials in the aqueous environment: Mechanistic considerations. Environ. Sci. Technol. 2002, 36, 3725-3734.

69. Bucheli, T.D. and Gustafsson, Ö Quantification of the soot-water distribution coefficient of PAHs provides mechanistic basis for enhanced sorption observations. Environ. Sci. Technol. 2000, 34, 5144-5151.

70. Koelmans, A.A.; Jonker, M.T.O.; Cornelissen, G.; Bucheli, T.D.; Van Noort, P.; Gustafsson, O. Black carbon: The reverse of its dark side. Chemosphere 2006, 63, 365377. 
71. Hawthorne, S.B.; Miller, D.J.; Grabanski, C.B. Measuring low picogram per liter concentrations of freely dissolved polychlorinated biphenyls in sediment pore water using passive sampling with polyoxymethylene. Anal. Chem. 2009, 81, 9472-9480.

72. Rose, N.; Jones, V.; Noon, P.; Hodgson, D.; Flower, R.; Appleby, P.G. Long-range transport of pollutants to the Falkland Islands and Antarctica: Evidence from lake sediment fly-ash particle records. Environ. Sci. Technol. 2012, 46, 9881-9889

73. Masiello, C. New directions in black carbon organic geochemistry. Mar. Chem. 2004, 92, 201-213.

74. Kraaij, R.; Mayer, P.; Busser, F.J.M.; van het Bolscher, M.; Seinen, W.; Tolls, J.; Belfroid, A.C. Measured pore-water concentrations make equilibrium partitioning work a data analysis. Environ. Sci. Technol. 2003, 37, 268-274.

75. Endo, S.; Escher, B.I.; Goss, K.U. Capacities of membrane lipids to accumulate neutral organic chemicals. Environ. Sci. Technol. 2011, 45, 5912-5921.

76. Jonker, M.T. What is causing biomagnification of persistent hydrophobic organic chemicals in the aquatic environment? Environ. Sci. Technol. 2012, 46, 110-111.

77. Martinson, D.G. Antarctic circumpolar current's role in the Antarctic ice system: An overview. Palaeogeogr. , Palaeoclimatol. , Palaeoecol. 2011, Volumes 335-336, 71-74 
TOC figure
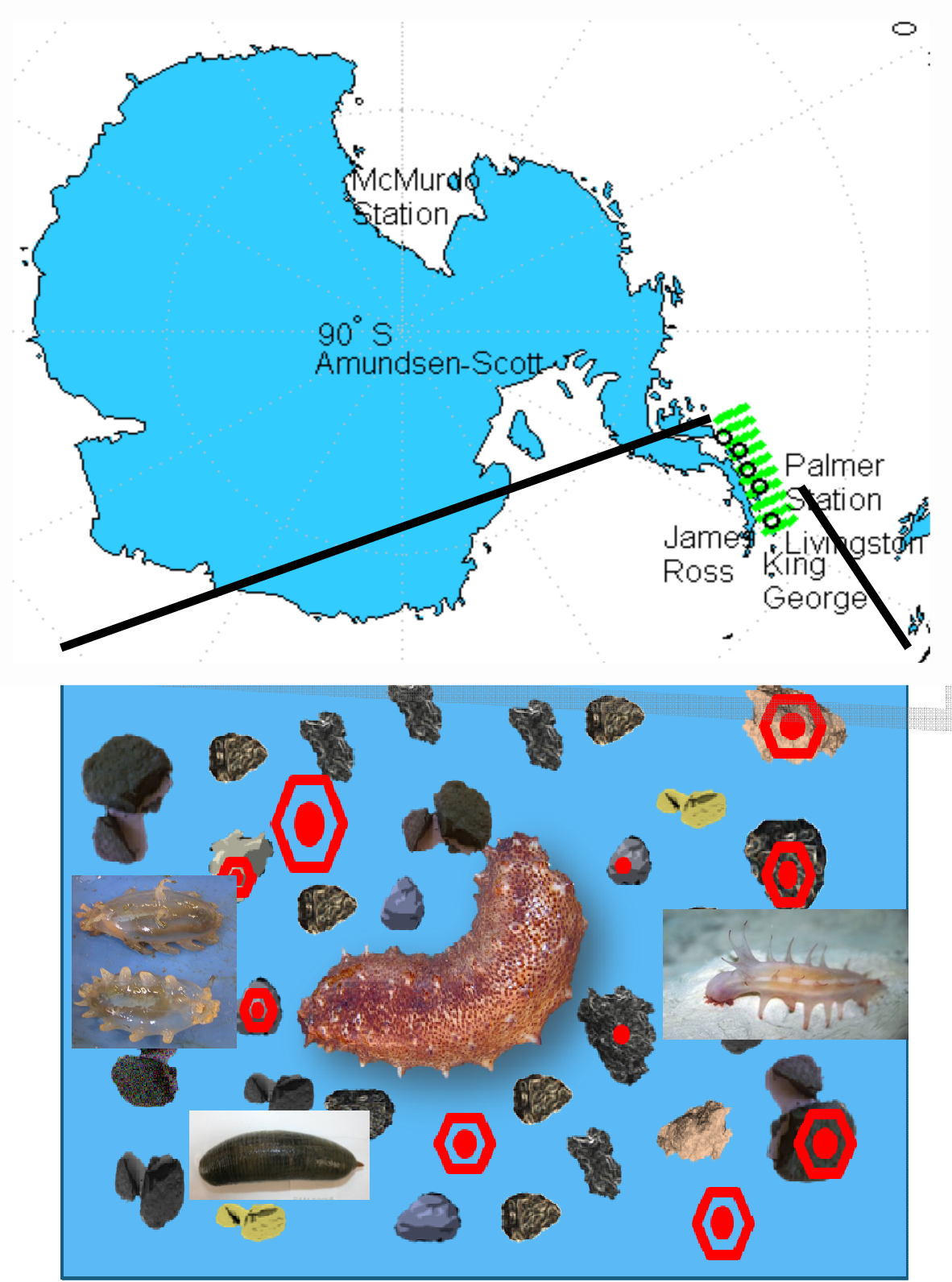